\title{
Analysis of Critical Success Factors for High Rise Buildings
}

\author{
Pankaj P. Bhangale \\ Associate Professor \& Head of Department \\ Civil Engineering Department \\ Shri SantGadge Baba College of Engineering and Technology, Bhusawal, India
}

\begin{abstract}
TheConstruction Industry is one of the very fast growing industries but it also faces many problems which invade on the performance of their projects. The aim of this study is to identify the critical success factors affecting the local construction projects and analyze them. A questionnaire is prepared from literature review. A comprehensive literature review was deployed to generate a set of factors believed to affect project enactment.The questionnaire contains two parts; part A dealing with the general information of the company and the respondent and Part B is subdivided again into different factors like cost, time, quality, client satisfaction, People factors, health and safety, innovation and learning and environment, project related, organization related, project manager and project team related and last is external environment related. The questionnaire was distributed to High Rise Building Projects in Mumbai. Each respondent was asked to rank the factors in a range of one to five in likert scale. The analysis of the response was done using the ranking method. The top 5 critical success factors affecting the performance of projects were identified as Average delay because of closures and materials shortage, Availability of personals with high experience and qualification, belonging to work, Learning from best practice and experience of others, Economic environment.
\end{abstract}

Key Words-Construction industry, performance, High Rise Structures.

\section{INTRODUCTION}

Construction industry plays foremost role in improvement and accomplishment of the target of society. Construction industry is one of the largest and it adds to about $10 \%$ of the gross national product (GNP) in industrialized countries. Construction industry is complex in its nature as it involves large number of parties such as clients, contractors, consultants, stakeholders, shareholders and regulators. The construction industry is generally considered to have underperformed compared to other industry. Not only that, some construction industry has been criticized for not performing at the same level as that of other developed countries. In relation to this, working groups on key performance indicators (KPI) have identified ten parameters for benchmarking projects, in order to achieve a good performance in construction industry.He studies of project success and the critical success factors (CSFs) are considered to be a means to improve the effectiveness of project.The term "critical success factors," in the context of projects and the management of projects, was first used by Rockart (1982) and is defined as those factors predicting success on projects (Sanvido et al. 1992). The topic has since become a prolific research area. Furthermore, because the pursuit of excellence in project delivery systems is not new, this new research direction could thrive upon a rich legacy of many previous investigators. However, the concept of project success has remained ambiguously defined in the mind of the construction professionals. $[9,10]$

Performance is associated with several factors such as time, cost, quality, client satisfaction, productivity and safety. There are other genuine reasons like closures, modification of drawings and changes of the design. Other grounds affecting construction projects performance are poor management and guidance; inapt participants; poor relations and coordination; lack of motivation, insufficient infrastructure, political problems, cultural problems and economic conditions. Iyer and Jha (2005) identified many factors as having influence on project cost performance, these include: project manager's competence, top management support, project manager's coordinating and leadership skills, monitoring and feedback by the participants, decision-making, coordination among project participants, owners' competence, social condition, economic condition, and climatic condition. Coordination among project participants, however, was identified as the most significant of all the factors, having maximum influence on cost performance.recognized coordination among participants, leadership skills and coordination of project managers, project manager's competence, support of the top management, economic and climatic condition, social condition, participant's coordination, decision making as key factors. [1]

Pinto and Slevin, and de Wit viewed success as being judged by the degree to which project objectives have been met. These views centered on success of project management delivery processes and also acknowledged that project success is also a matter of the project stakeholder's perception of the value (in their terms) of what was delivered. [6,7] 
Project success factors defined by Cooke-Davies are the inputs to management system that lead directly or indirectly to success of the project. He tried to answer three basic questions in order to find out the critical success factors that affect the performance ofany project, namely: What factors lead to a project management success, what factors lead to a successful project and what factors lead to consistently successful projects. He identified critical factors that affect the performance of projects.[8]

In this study, factors affecting the performance of construction projects in the regions of Mumbai, Pune and Nashik will be analyzed. Critical success factors are used to measure performance in construction projects. Then these indicators will be used as, a key element of any organizations step in achieving best practice so as to conquer the performance and success problem. However, this study aims at identifying the factors which are affecting the performance of construction projects and the analysis of the factors using the ranking method with likert scale and finding the ranking positions of factors accordingly.

\section{AIM AND OBJECTIVE}

The aim and objective of the study is to find the factors which affects the performance of the construction projects in and around the regions ofMumbai, Pune and Nashik.

1. To find the critical success factors influencing the performance of construction projects.

2. Evaluation of the factors and ranking the factors according to the ranking position.

3. To give suggestions and recommendations to mend the performance of the industry.

\section{STATEMENT OF THE PROBLEM}

One of the most significant problems facing construction projects in developing countries is the lack of consideration and planning in the pre-implementation stage, as well as the failure of projects during their execution. As a result, the desired goals are neither achieved nor integrated with the general developmental or economic strategy of the country. Whilst there is also a lack of methods and mechanisms to monitor and control projects, as can be the case in developed countries, some research has been undertaken in developed countries regarding how to control and measure the performance of construction projects. Therefore, these are investigated to select suitable methods and appropriate mechanisms that can be applied to address the poor performance of construction projects. However, a CSF is anticipated to address and remedy these issues involving institutional aims, plans, goals and strategies. Figure 1.1 shows the background of problem.

Figure 1: Background of the Problem.

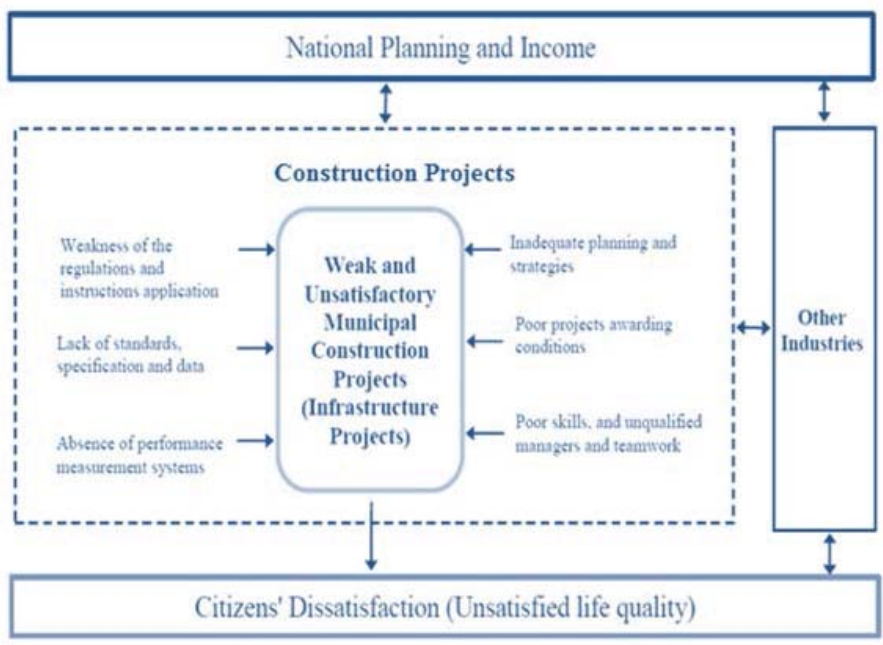

\section{RESEARCH METHODOLOGY}

A. From the literature reviews, factors concerning the critical success of the projects were collected and the questionnaire was prepared.

B. The questionnaire included questions from cost, time, quality, client satisfaction, People factors, health and safety, innovation and learning and environment, project related, organization related, project manager and project team related and last is external environment related.

C. The questionnaires were distributed to contractors. Mainly the regions covered wereMumbai, Pune and Nashik.

D. Respondents were asked to rank the questions from one to five based on their importance like very low, low, medium high and very high. 
E. Based up on the responses received the questionnaire analysis was done by ranking method.Relative importance index was used to determine the relative significance and ranking of the causes.

F. Relative importance index RII is calculated as follows

$\mathrm{RII}=\sum \mathrm{W} \div(\mathrm{A} * \mathrm{~N})$

Where, $\mathrm{W}=$ weightage given to each factor by the respondent.

$\mathrm{A}=$ highest weightage given

$\mathrm{N}=$ total number of respondents.

G. The questionnaires were distributed to Project Manager, organization manager, site engineer and contractor of organizations and responses are collected for analysis.

Figure2: Flow Chart showing Methodology.

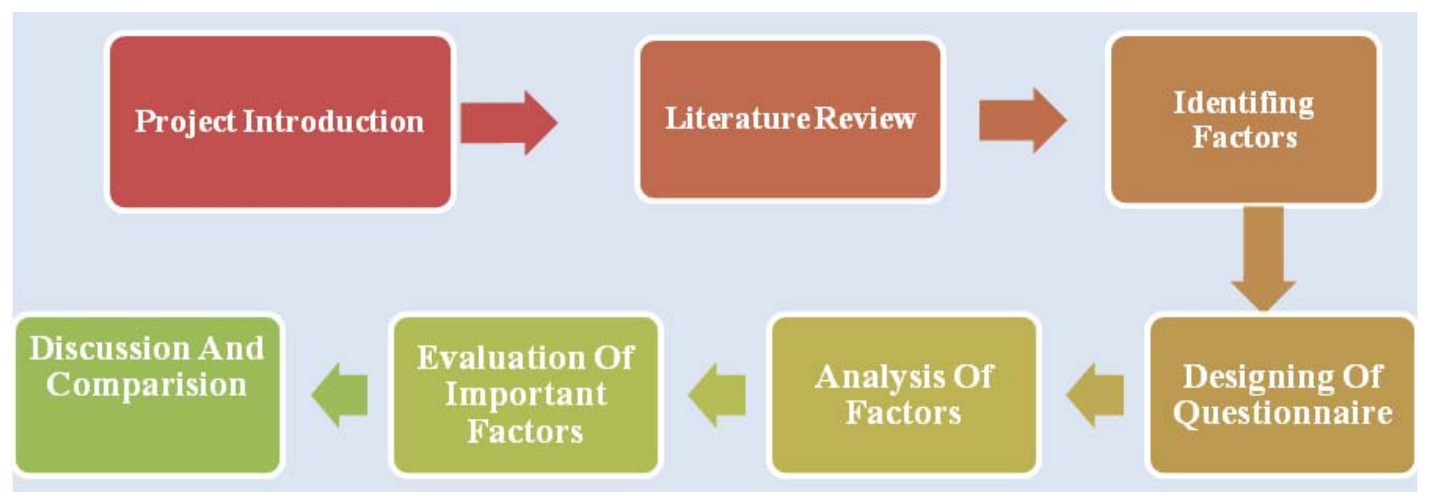

\section{DATA COLlECTION AND ANALYSIS}

Data collection from High Rise building project Mumbai through distributing the Questionnaires to respondents in the form of Likert scale (1 to 5) of which ' 1 ', '2', '3', '4', \& '5' stands for 'Strongly Agree', 'Agree', 'Moderately Agree', 'Disagree' and 'Strongly Disagree' respectively. Further Analysis is done on basis on responses collected and tabulated as below.

Table no. 1: Summary of relative importance index and rank for factors affecting the performance of construction projects

\begin{tabular}{|l|l|l|c|c|}
\hline $\begin{array}{l}\text { Sr. } \\
\text { No. }\end{array}$ & Identified Factors & RII & $\begin{array}{c}\text { overall } \\
\text { rank }\end{array}$ & $\begin{array}{c}\text { factor } \\
\text { wise rank }\end{array}$ \\
\hline & (1) Cost Factors & & & \\
\hline 1 & Market share of organization & 0.4333 & 16 & 8 \\
\hline 2 & Liquidity of organization & 0.9 & 3 & 2 \\
\hline 3 & Cash flow of project & 0.9333 & 2 & 1 \\
\hline 4 & Profit rate of project & 0.6333 & 11 & 5 \\
\hline 5 & Overhead percentage of project & 0.5333 & 13 & 6 \\
\hline 6 & Material and equipment cost & 0.9333 & 2 & 1 \\
\hline 7 & Project design cost & 0.4 & 17 & 9 \\
\hline 8 & Project labor cost & 0.8333 & 5 & 3 \\
\hline 9 & Project overtime cost & 0.5 & 14 & 7 \\
\hline 10 & Escalation of material prices & 0.9 & 3 & 2 \\
\hline 11 & Cost control system & 0.7 & 9 & 4 \\
\hline 12 & Regular project budget update & 0.5333 & 13 & 6 \\
\hline 13 & Waste rate of materials & 0.4 & 17 & 9 \\
\hline 14 & Cost of rework & 0.3333 & 19 & 10 \\
\hline 15 & Cost of variation orders & 0.5333 & 13 & 6 \\
\hline & (2) Time Factors & & & \\
\hline 16 & Site preparation time & 0.4333 & 16 & 7 \\
\hline 17 & Planned time for project Construction & 0.7333 & 8 & 5 \\
\hline 18 & Time needed to implement variation orders & 0.4667 & 15 & 6 \\
\hline
\end{tabular}




\begin{tabular}{|c|c|c|c|c|}
\hline $\begin{array}{l}\text { Sr. } \\
\text { No. }\end{array}$ & Identified Factors & RII & $\begin{array}{c}\text { overall } \\
\text { rank }\end{array}$ & $\begin{array}{c}\text { factor } \\
\text { wise rank }\end{array}$ \\
\hline 19 & Percentage of orders delivered Late & 0.8 & 6 & 3 \\
\hline 20 & Average delay in claim approval & 0.8 & 6 & 3 \\
\hline 21 & Average delay in payment from owner to contractor & 0.7667 & 7 & 4 \\
\hline 22 & Time needed to rectify defects & 0.2667 & 20 & 8 \\
\hline 23 & $\begin{array}{l}\text { Availability of resources as planned through project } \\
\text { duration }\end{array}$ & 0.9333 & 2 & 2 \\
\hline \multirow[t]{2}{*}{24} & $\begin{array}{l}\text { Average delay because of closures and materials } \\
\text { shortage }\end{array}$ & 0.9667 & 1 & 1 \\
\hline & (3) Quality Factors & & & \\
\hline 25 & Conformance to specification & 0.8667 & 4 & 2 \\
\hline 26 & $\begin{array}{l}\text { Availability of personals with high experience and } \\
\text { qualification }\end{array}$ & 0.9667 & 1 & 1 \\
\hline 27 & Quality training/meeting & 0.3667 & 18 & 6 \\
\hline 28 & Quality assessment system in Organization & 0.5 & 14 & 5 \\
\hline 29 & $\begin{array}{l}\text { Participation of managerial levels with decision } \\
\text { making }\end{array}$ & 0.5667 & 12 & 4 \\
\hline \multirow[t]{2}{*}{30} & Quality of equipment and raw materials in project & 0.6667 & 10 & 3 \\
\hline & (4) Client Satisfaction factors & & & \\
\hline 31 & $\begin{array}{l}\text { Information coordination between owner and } \\
\text { project parties }\end{array}$ & 0.6333 & 11 & 3 \\
\hline 32 & Leadership skills for project manager & 0.8 & 6 & 1 \\
\hline $\begin{array}{l}\text { Sr. } \\
\text { No. }\end{array}$ & Identified Factors & RII & $\begin{array}{c}\text { overall } \\
\text { rank }\end{array}$ & $\begin{array}{c}\text { factor } \\
\text { wise rank }\end{array}$ \\
\hline 33 & Speed and reliability of service to owner & 0.7333 & 8 & 2 \\
\hline 34 & $\begin{array}{l}\text { Number of disputes between owner and project } \\
\text { parties }\end{array}$ & 0.7333 & 8 & 2 \\
\hline \multirow[t]{2}{*}{35} & Number of reworks & 0.5 & 14 & 4 \\
\hline & (5) People factors & & & \\
\hline 36 & Employee attitudes in project & 0.7 & 9 & 3 \\
\hline 37 & $\begin{array}{l}\text { Recruitment \& competence development between } \\
\text { employees }\end{array}$ & 0.7667 & 7 & 2 \\
\hline 38 & Employees motivation & 0.5667 & 12 & 4 \\
\hline \multirow[t]{2}{*}{39} & Belonging to work & 0.9667 & 1 & 1 \\
\hline & (6) Health and Safety factors & & & \\
\hline 40 & $\begin{array}{l}\text { Application of Health and safety factors in } \\
\text { organization }\end{array}$ & 0.9333 & 2 & 1 \\
\hline 41 & Easiness to reach to the site (location of project) & 0.7 & 9 & 2 \\
\hline 42 & Reportable accidents rate in project & 0.5333 & 13 & 3 \\
\hline \multirow[t]{2}{*}{43} & Assurance rate of project & 0.3333 & 19 & 4 \\
\hline & (7) Innovation and learning factors & & & \\
\hline 44 & $\begin{array}{l}\text { Learning from own experience } \\
\text { and past history }\end{array}$ & 0.8333 & 5 & 2 \\
\hline 45 & $\begin{array}{l}\text { Learning from best practice and experience of } \\
\text { others }\end{array}$ & 0.9667 & 1 & 1 \\
\hline 46 & Review of failures and solve them & 0.7 & 9 & 3 \\
\hline 47 & $\begin{array}{l}\text { Training the human resources in the skills } \\
\text { demanded by the project }\end{array}$ & 0.6667 & 10 & 4 \\
\hline \multirow[t]{2}{*}{48} & Work group & 0.5333 & 13 & 5 \\
\hline & (8) Environment factors & & & \\
\hline 49 & Air quality & 0.6333 & 11 & 3 \\
\hline 50 & Noise level & 0.5 & 14 & 4 \\
\hline 51 & Climate condition in the site & 0.9333 & 2 & 1 \\
\hline \multirow[t]{2}{*}{52} & Wastes around the site & 0.7 & 9 & 2 \\
\hline & (9) Project Related Factors & & & \\
\hline 53 & The size and the value of the project & 0.9333 & 2 & 1 \\
\hline 54 & The uniqueness of the project activities & 0.6333 & 11 & 4 \\
\hline
\end{tabular}




\begin{tabular}{|l|l|l|c|c|}
\hline $\begin{array}{l}\text { Sr. } \\
\text { No. }\end{array}$ & Identified Factors & RII & $\begin{array}{c}\text { overall } \\
\text { rank }\end{array}$ & $\begin{array}{c}\text { factor } \\
\text { wise rank }\end{array}$ \\
\hline 55 & The density of project network & 0.6333 & 11 & 4 \\
\hline 56 & Project life cycle & 0.8 & 6 & 3 \\
\hline 57 & The urgency of a project outcome. & 0.8667 & 4 & 2 \\
\hline & $\begin{array}{l}\text { Fo) Project Manager And Team Related } \\
\text { Factors }\end{array}$ & & \\
\hline 58 & Ability to delegate the authorities. & 0.7333 & 8 & 3 \\
\hline 59 & Ability of trade off & 0.7333 & 8 & 3 \\
\hline 60 & Ability to coordinate & 0.8333 & 5 & 2 \\
\hline 61 & Perception of role and responsibilities & 0.7333 & 8 & 3 \\
\hline 62 & Commitment & 0.6333 & 11 & 5 \\
\hline 63 & Trouble shooting & 0.6667 & 10 & 4 \\
\hline 64 & Communication skill & 0.9 & 3 & 1 \\
\hline & (11) Factors Related To Organization & & & \\
\hline 65 & Top management support & 0.8667 & 4 & 1 \\
\hline 66 & Project organizational structure & 0.5667 & 12 & 3 \\
\hline 67 & Functional manager's support & 0.7333 & 8 & 2 \\
\hline 68 & Project champion & 0.5 & 14 & 4 \\
\hline & (12) External Environment Related Factors & & & \\
\hline 69 & Economic environment & 0.9667 & 1 & 1 \\
\hline 70 & Political environment & 0.7 & 9 & 4 \\
\hline 71 & Social environment & 0.6667 & 10 & 5 \\
\hline 72 & Technological environment & 0.8333 & 5 & 2 \\
\hline 73 & Client & 0.6667 & 10 & 5 \\
\hline 74 & Competitors & 0.6333 & 11 & 6 \\
\hline 75 & Sub-contractors & & \\
\hline
\end{tabular}

\section{RESULT AND DISCUSSION}

Table no. 2: The top significant factors affecting the performance of construction projects

\begin{tabular}{|c|l|c|c|}
\hline Sr. No. & Factors & RII & Rank \\
\hline 1 & Average delay because of closures and materials shortage & 0.9667 & 1 \\
\hline 2 & $\begin{array}{l}\text { Availability of personals with high experience and } \\
\text { qualification }\end{array}$ & 0.9667 & 1 \\
\hline 3 & Belonging to work & 0.9667 & 1 \\
\hline 4 & Learning from best practice and experience of others & 0.9667 & 1 \\
\hline 5 & Economic environment & 0.9667 & 1 \\
\hline 6 & Cash flow of project & 0.9333 & 2 \\
\hline 7 & $\begin{array}{l}\text { Availability of resources as planned through project } \\
\text { duration }\end{array}$ & 0.9333 & 2 \\
\hline 8 & Application of Health and safety factors in organization & 0.9333 & 2 \\
\hline 9 & Climate condition in the site & 0.9333 & 2 \\
\hline 10 & The size and the value of the project & 0.9333 & 2 \\
\hline
\end{tabular}

A. The factors which are ranked as number 1 with RII being 0.9667 . Delay caused due to closures and material shortage are ranked high by all companies as materials are the most basic things required to complete a project. Highly experienced personnel will carry out the work with great efficiency. Also, in order to improve one's working technique, it is essential to be able to grasp important skills and qualities from best practices performed in the industry. Also among the factors associated with the external environment, economic environment has great impact on the project performance and success of a company. 
B. All these factors have RII of 0.9333. Project cash flow is very important in determining the level of performance as the entire working of the project activities is centered around cash inflow and outflow. Among all the surveyed companies, only the newly developed Constructions has rated cash flow as medium important factor. Availability and cost of resources such as materials and equipment are also major factors deciding the execution process of the project as the project can only carry on if the resources are available at planned time and also with reasonable cost fitting into company's budget.

C. Cost group has been ranked by the respondents in the eleventh position with RII equal 0.633 . This group is more important for consultant than for others because liquidity of organization and project design cost affect the project cost performance and this is related to owner satisfaction. Cost group affects strongly the performance of construction projects and it can be one of the most important indicators to measure performance as cost is considered as an important criterion for judgment of construction projects performance.

D. Health and safety group has been ranked by the respondents in the twelfth position with RII equal 0.625 . It is obtained that this group is not important for parties because safety is rarely considered or applied through implementation stage of construction projects. Health and safety group affects the performance of construction projects due to different location, culture and management style.

E. Some other important and majorly effective factors as ranked by the companies are liquidity of organization, escalation of material prices, communication skill, conformance to specification, etc. Here, liquidity of organization refers to organization's ability to convert assets into cash and maintain an uninterrupted cash flow. Thus it will clearly affect the performance to a considerable extent and thus, is rated as important by the respondents. Another important factor is escalation of prices in the market which needs to be taken into consideration while planning and scheduling the project as well as at the time of procuring required materials. Regarding the quality aspect, it is necessary for the outcome or the end result of each milestone of the project matches with the specifications determined in the planning phase. Also, another major factor responsible for healthy working environment and thus leading to satisfactory project performance and success is the communication skills of the entire project staff including higher authority or management personnel as well as site workers.

Chart no. 1: Average RII for the groups effecting the critical success factor and performance of the construction projects.

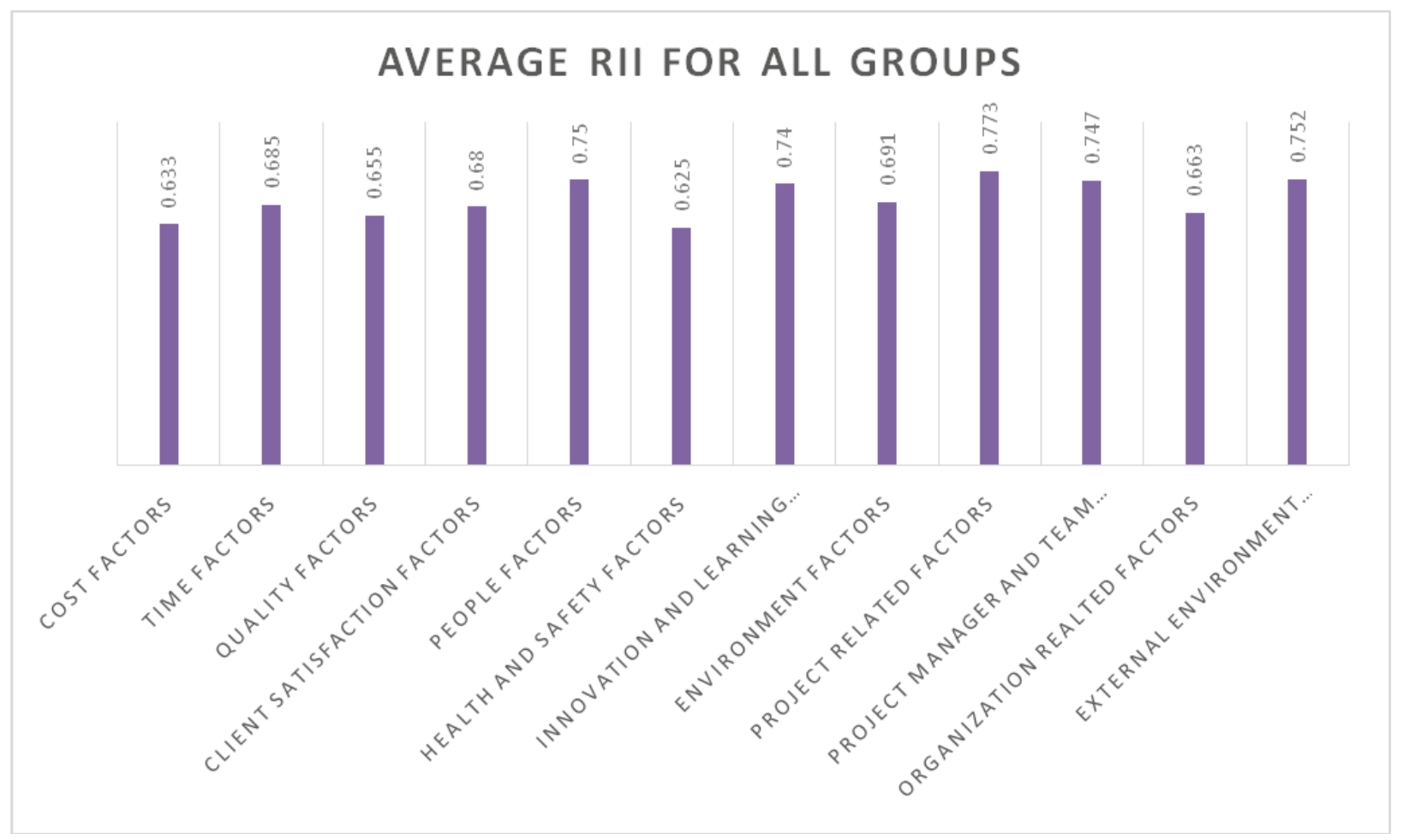




\section{CONCLUSION}

1. This study will give an overview of several factors affecting the success of a project, with the help of PMS (Performance Measurement System) and CSF (critical success factors) and will help to determine the most critical factors affecting the success of a construction company regarding satisfactory performance.

2. Delay caused due to closures and material shortage, Availability of personnel with high experience, belonging to work, learning from best practice and experience of others, Economic environment are the factors identified as the most critical factors for performance of the construction projects in Mumbai, Pune and Nashik region.

3. From the data from all companies, it can be seen that the factors associated with quality and client satisfaction are rated at considerably lower positions. However, I would suggest that more importance be given to these factors as according to our basic framework regarding the problems associated with the construction industry. The resolution of these problems ultimately is aimed towards client satisfaction which is again concerned with the quality of the finished product.

4. Basically, it can be briefly concluded that for successful completion of a construction project, various factors are responsible which need to be considered for developing a proper performance measurement system. Out of these factors, most critical ones have to be attended to with great care. And by understanding the relationship between all these critical factors, necessary changes should be made in the working strategy of the company in order to achieve a greater level of success with a better project performance.

\section{ACKNOWLEDGMENT}

I would like to express my profound gratitude and great appreciation to Dr. G.R. Seolakar and Dr. J. S. Chauhan for his encouragement, valuable advice, constructive suggestions, tireless guidance and enduring patience throughout this study.

\section{REFERENCES}

[1] Iyer, K. C.; Jha, K.," Factors affecting cost performance: evidence from Indian construction projects", International Journal of Project Management 23: 283-295, November 2005

[2] Kuprenas, J. A.,'Project management actions to improve design phase cost performance", Journal of Management in Engineering 19(1): 25-32, 2003

[3] Brown, A.; Adams, J. 2000. Measuring the effect of project management on construction outputs: a new approach, International Journal of Project Management 18: 327-335.

[4] Ugwu, O.O. and Haupt, T.C., (2007). Key Performance Indicators and Assessment Methods for Infrastructure Sustainability - A South African Construction Industry Perspective, Building and Environment, Vol. 42, PP. 665-680.

[5] Atkinson, R. (1999). Project Management: Cost, Time and Quality, Two Best Guesses and a Phenomenon, It's Time to Accept Other Success Criteria. International Journal of Project Management 17 (6): 337-342.

[6] Anton de Wit, (August 1988), "Measurement of project success", Journal of Project Management, 6(3), pp.no.164-170.

[7] J. K. Pinto and, D. P. Slevin, (1987) "Critical factors in successful project implementation", IEEE Transactions on Engineering Management, 34(1), pp no.22-27.

[8] Terry Cooke-Davies, (2002) “The Real Success Factors on Projects”, International Journal of Project Management, 20, pp.185-190.

[9] Sanvido, V., Grobler, F., Pariff, K., Guvents, M., and Coyle, M. (1992). "Critical success factors forconstruction projects.” J. Constr. Eng. Manage., 118(1), $94-111$.

[10] Rockart, J. F. (1982). "The changing role of the information systems executive: A critical success factorsperspective." Sloan Mgmt. Review, 24(1), 3-13.

[11] Guru Prakash Prabhakar, (September 2008) "What is Project Success: A Literature Review", International Journal of Business and Management, 3(9), pp no.3-10

[12] AmakaOgwueleka(april2011) "The Critical Success Factors Influencing Project Performance in Nigeria", International Journal of Management Science and Engineering Management, 6(5), pp.no343-349.

[13] AfshinPakseresht and Dr. GholamrezaAsgari, (December 2012) "Determining the Critical Success Factors in Construction Projects: AHP Approach", 4(8), Pp no.383-393.

[14] Ashok K. Pundir, L.Ganapathy and RashmiShahu, (October-December 2011) "Success Factors For Construction Projects: A Survey Of Selected Projects", Nicmar Journal Of Construction Management ISSN No.0970-3675, Volume Xxiv, pp no.5-18.

[15] Hari Garbharran, JeevarathnamGovender\&ThulaniMsani, (2012) "Critical success factors influencing project success in the construction industry", Critical success factors; pp no. 90-108. 